\title{
Facies architecture and depositional evolution of Palaeocene-Eocene, Subathu Formation, Garhwal Himalaya, Uttarakhand, India
}

\author{
S R Mishra ${ }^{1, *}$, Rabisankar Karmakar ${ }^{2}$, SAtish C Tripathi $^{3}$, \\ Mridul Gupta ${ }^{1}$ and Rajuram Sarswat ${ }^{4}$ \\ ${ }^{1}$ Geological Survey of India, Northern Region, Lucknow, India. \\ ${ }^{2}$ Geological Survey of India, Eastern Region, Kolkata, India. \\ ${ }^{3}$ Geological Survey of India, Southern Region, Hyderabad, India. \\ ${ }^{4}$ Geological Survey of India, Western Region, Jaipur, India. \\ *Corresponding author. e-mail: shruti.ism@gmail.com
}

MS received 6 September 2017; revised 17 July 2018; accepted 12 September 2018; published online 22 March 2019

The Late Palaeocene-Middle Eocene marine sedimentary sequence of the Himalayan foreland basin, represented by the rocks of Subathu Formation, is enriched with the presence of foraminifera, bryozoa, corals, gastropods, bivalves and so on within both carbonate and clastic dominant lithologies. The carbonate and the shale consist mainly of larger benthic foraminifera (LBF) and the assemblage is composed of Nummulites and Assilina along with the other skeletal and non-skeletal components. The presence of a palaeosol at the base of Subathu indicates a gap in sedimentation. The lithological and biotic assemblages along with the bed form, bed geometry and primary sedimentary features helped us to establish four facies associations, A, B, C and D, and have been corroborated with the shoreline migration (transgression/regression) history. The facies association-A, representing the basal horizons of Subathu Formation, indicates the onset of transgression and deposition in lagoonal condition with carbonaceous shale and oolitic ironstone, followed by the facies association-B and $-\mathrm{C}$ deposited in shallow marine shoreface. The uppermost unit, i.e., the medium- to coarse-grained sandstone (facies association-D) of Subathu Formation, represents a fall in relative sea level (progradational stacking pattern), whereas the underlying contact between the facies association-B and - $\mathrm{C}$ is represented by an aggradational stacking pattern between the siltstone and the shale, but certainly without exposing the shelf. Petrographic studies based on characteristic features such as framework constituent, the percentage of matrix and grains, nature of cementing material, textural features and fossil content help to deduce a distinct change in depositional setting from an open marine (shelf) to shoal, a lagoon that gradually grades to foreshore/beach environment. The study reveals that the basin has gone through a transgressive (facies association-A and -B), regressive (facies association-C) as well as distinct forced regressive (facies association-D) phase of shoreline migration history.

Keywords. Subathu Formation; facies association; benthic foraminifera; Garhwal Syncline. 


\section{Introduction}

In recent years, the basin scale depositional analysis experienced a trend shift with the spatiotemporal facies analysis with respect to extraand intra-basinal inputs. The lesser Himalayan sedimentary sequence provides an unparalleled opportunity to examine the complex ways in which the sedimentation has taken place. The continentcontinent collisional tectonics resulted in the formation of peripheral foreland basin and associated sequential changes (Ziegler et al. 1995, 1998). Thus, the architecture of the thick pile of foreland sediments holds meaningful clues for the past climate, tectonic and depositional activities operated at the different stages of mountain building processes (Allen et al. 1991; DeCelles and Giles 1996; Sinclair 1997). The foreland sedimentation from transitional marine to continent passes through several stages by means of the shallow water to fluvial deposits (Allen et al. 1991; Sinclair 1997). Although such transition and its signatures have earlier been reported from the northwestern Himalayan foreland, the facies architecture of marine Subathu Formation, both in time and space in the Garhwal Syncline, northwestern Himalaya is poorly documented.

The Palaeogene succession of the Himalayan foreland basin is immensely important as it is the period related to the suturing of the Indian plate with the Asian plate and the commencement of mountain-building events vis-à-vis basin evolution. During the Palaeogene, the shoreline migration inward to the Indian plate and changing depositional environment from swamp-lagoon environment to finally foreshore/beach environment through shoreface indicates marine transgression and regression (Mathur 1978; Sarkar and Prasad 2000; Bera et al. 2008, 2010; Bera and Mandal 2013; Singh et al. 2010; Singh 2012, 2013). The Palaeogene Subathu Formation preserves the evidence of last marine transgression in the Himalayan fold-thrust belt and spatially disposed in different synclines of $\mathrm{N}-\mathrm{W}$ Himalaya owing to later tectonics (Bhatia 1985; Najman et al. 1993). It is an important lithostratigraphic unit to unravel the shoreline migration history.

The present study focuses on criterion-based interpretation of the depositional environment and shoreline migration history with the help of field evidences as well as through the petrographic characterisation of the individual facies types. Furthermore, these outcomes have been corroborated to propose a simplified three-dimensional model to explain the basin scale depositional history.

The Late Palaeocene-Middle Eocene strata of Subathu Formation also preserve the wide variability of larger benthic foraminifera (LBF). These foraminifera thrived in the shallow shelf carbonate platforms and have a unique character of being a rock forming biota. Due to the bottomdwelling character of foraminifera in a wide range of platformal environments, these biotas are influenced by global and local factors such as sea level changes, tectonics of upliftment or subsidence, trophic sources and so on. The variation of these parameters affects the biotic composition and the abundance of biota (Chaproniere 1975; Hottinger 1983, 1997). The LBF (Nummulite and Assilina) have been used as a major tool for petrographic characterisation of the Subathu sediments and hence the depositional history. The representative sections were studied in the Garhwal Syncline, lesser Himalaya.

\section{Material and methodology}

Lithological sections of Subathu Formation are exposed in the core part of various synclines of lesser Himalaya. The present study is carried out in the Garhwal Syncline, Uttarakhand (figure 1). The Subathu Formation varies in its thickness and may not be laterally persistent owing to its structural pinching and later tectonics. Traverses were taken in strike parallel, NW-SE trending syncline at different locations to understand and study the lateral and vertical variability/correlatability of the lithologies. Although measuring the true thickness of sedimentary sequences in structurally deformed and overprinted terrain like Himalaya always remains a challenge, utmost precautions have been taken to avoid the repetition of a particular horizon in all the measured sections. For delineating the facies types, genetically related lithologies/subfacies were clubbed under a particular facies, and mutually associated facies types were grouped under facies associations. A wide variety of rock types ranging from shale, siltstone and sandstone to carbonate (limestone) were characterised on the basis of field criteria including bedding features, bed geometry, faunal composition, primary sedimentary structures (cross-bedding, wave features and burrowing) and diagenetic features.

Fifty-two thin sections were prepared and studied in detail under the petrological microscope. 


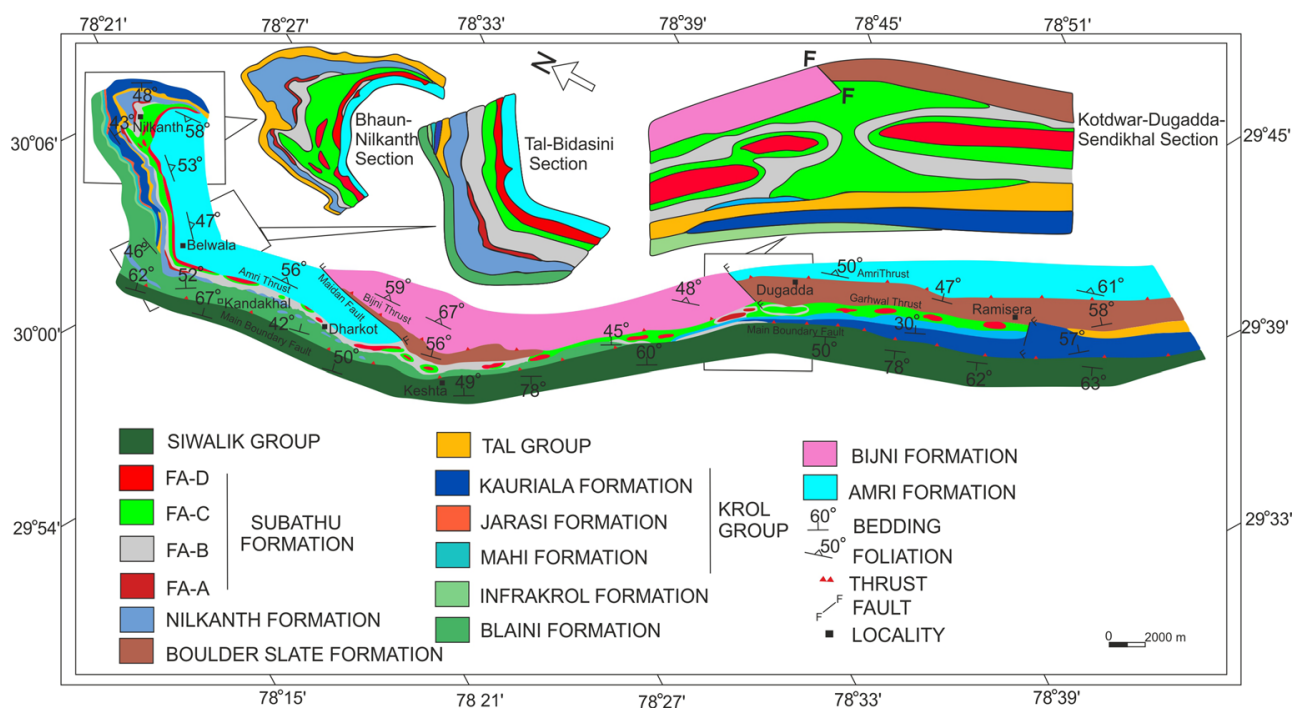

Figure 1. Geological map of the area showing the Subathu Formation and associated litho successions of Garhwal Syncline, Uttarakhand.

Based upon a percentage of matrix and grain, textural characteristics, nature of cement and biota composition (mainly LBF), the petrographic characterisation of the rocks of Subathu Formation was established. The composition of associated fauna (presence of echinoids, molluscs and bryozoans) and non-skeletal grains (e.g., ooids, intraclasts and peloids) were also considered in the classification scheme.

\section{Geological setting and a brief overview of the earlier studies}

The lesser Himalayan group of rocks, irrespective of their age, i.e., proterozoic, palaeozoic, mesozoic or cenozoic (palaeogene only), are thrusted over sub-Himalayan (Siwalik Group) sediments along with the main boundary thrust (MBT). Lithostratigraphically, the Palaeogene succession of lesser Himalaya is subdivided into marine Subathu, continental molasse Dagshai and fresh water deposit of Kasauli Formations in the ascending order (Medlicott 1864). The marine Subathu Formation comprises an essential litho- and biostratigraphic horizon of the lesser Himalayan belt and is disposed in various synclines. The measured thickness of Subathu Formation varies from about $175 \mathrm{~m}$ in Jammu and Kashmir (in the northwest) and $400 \mathrm{~m}$ in Himachal Pradesh to about 170 $\mathrm{m}$ in Uttarakhand (in the southeast; Medlicott 1864). It rests largely on Precambrian basement, except in the Dugadda and Nilkanth localities (Uttarakhand), where it overlies Upper Cretaceous
Nilkanth Formation (Valdiya 1980), and indicating profuse unconformity at the base. The basement rock underlying the Subathu Formation is Maastrichtian Nilkanth/Singtali Formation (= shell limestone) in Uttarakhand (Auden 1937; Bhatia 1982; Mathur and Juyal 2000).

The basal lithounits of the Subathu Formation exhibit a great variation in different parts of northwestern Himalaya. It comprises carbonaceous shale with few impure coal seams, shale, limestone and sandstone sequence in Jammu area; carbonaceous shale, limestone and marly limestone in Himachal/Shimla area; and oolitic shelly limestone in the Uttarakhand (Mathur 1978). Bera et al. (2010) and Bera and Mandal (2013) studied the force regressive shoreface sandstone from Himalayan foreland for the marine to continental transition to imply for early Himalayan tectonic evolution and to establish the Oligo-Miocene unconformity. Based on the facies association, sedimentary structures and foraminifera, Singh (2012, 2013) interpreted the depositional environment and palaeobathymetry of the early Himalayan Foreland basin that the Subathu sequence developed in ephemeral streams, barriers, lagoons, swamps and tidal flat condition of the environment.

The present study is based on the lithounits of Subathu Formation, exposed in the southern limb of Garhwal Syncline as a NW-SE striking linear belt $(\sim 80 \mathrm{~km})$, extending from Rishikesh in the west to Ramisera in the east (figure 1). It rests either over the quartzite of Tal Group (Cambrian) or shell limestone of Nilkanth Formation (cretaceous) along with a regional unconformity. 

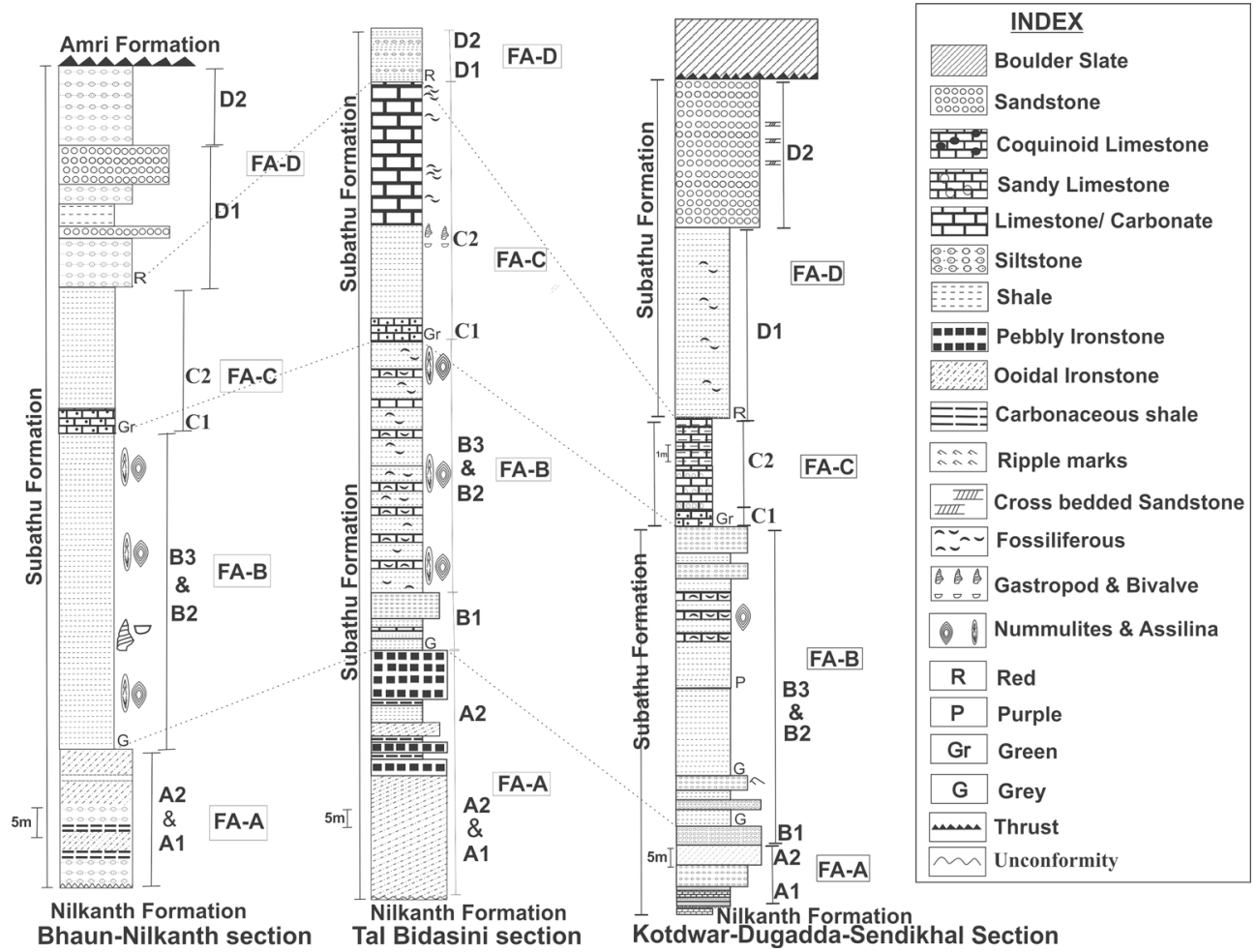

Figure 2. Correlation lithology showing the variation of Subathu Formation in Garhwal Syncline, Uttarakhand.

A thin palaeosol horizon demarcates the unconformity plane and is well exposed near Marora and Kandakhal, Uttarkhand. The litho-successions of Subathu are not much extended towards the northern side of the southern limb in the Garhwal Syncline because of being intersected by the Bijni Thrust. Three best exposed litho-sections of Subathu Formation, namely, the KotdwarDugadda-Sendikhal section, the Tal-Bidasini section and the Bhaun-Nilkanth section marked by their variable lithological characteristics were selected for the detailed study (figure 2). Four major subdivisions of Subathu Formation are mapped and delineated based upon the lithocharacteristics, bedforms and palaentological inputs and named as facies association-A, -B, $-\mathrm{C}$ and $-\mathrm{D}$ in the ascending order. These facies associations are nothing but the member level classification of Subathu Formation disposed from the periphery to core of the Garhwal Syncline.

The overall litho-assemblage of Subathu Formation from bottom to top, though not ubiquitously exposed, shows laterally correlatible characters. The basal part of Subathu Formation (figure 2) is represented by the black/dark grey shale, calcareous siltstone, thin bands of marly and earthy limestone and ooidal ironstone, which is succeeded by the grey nummulitic shale with lenticular sandstone grading upward to an intercalated sequence of the coquina limestone, grey shale and siltstone. The third distinguishable lithopackage upward is the intercalated sequence of green shale, siltstone and fine-grained sandstone containing bivalves. However, the occasional interbedded limestone is also recorded as in Tal-Bidasini and Bhaun-Nilkanth sections (figure 2). Further upward is the striking sequence of dominated shale with thin intermittent bands of sandstone and shell limestone. The Subathu Formation ends with relatively coarser, texturally and mineralogically mature grey coloured sandstone at the top.

\section{Facies architecture}

The Subathu Formation of Garhwal Syncline is subdivided into four major facies associations, namely, facies association-A (barrier bar or lagoonal), facies association-B (lower shoreface), facies association-C (upper shoreface) and the facies association-D (foreshore). Attempts have been made to simplify the facies architecture and nomenclature by clubbing all the genetically related lithounits for better understanding. Different lithounits have separately been clubbed, based 
on their genetic association, sediment supply, and rise and fall of the sea level (table 1).

\subsection{Facies association- $A$}

Facies association-A is the basal or lowermost facies association. It has further been divided into two facies types, i.e., $\mathrm{A}_{1}$ and $\mathrm{A}_{2}$, by clubbing the genetically related subfacies/lithologies. These facies types grade into one another both vertically as well as laterally within a short distance. Facies $\mathrm{A}_{1}$ comprises thinly laminated and splintery carbonaceous shale, basal nodular sandstone, and grey silty shale, marly and calcareous siltstones. The fissility planes are very well developed. Indistinct wave features are also present. The shale is dark grey to black in colour. Facies $\mathrm{A}_{2}$ is characterised by ooidal ironstone along with the chemically altered sandstone. This is a distinct unit in the basal part of the Subathu Formation and acts as a marker horizon indicating the onset of Subathu sedimentation. It is thickly bedded to massive, dense and fine- to medium-grained sequence.

Facies $A_{1}$ is not ubiquitously exposed and is restricted to areas such as Nilkanth, Tal Bidasini and Marora (figure 2). In the Dugadda area, the intercalated sequence of facies $A_{1}$ and $A_{2}$ has been recorded. The thickness of facies $A_{1}$ varies from 8 to $20 \mathrm{~m}$, whereas facies $A_{2}$ is $1-4 \mathrm{~m}$ thick. Near Dugadda, $A_{1}$ is mainly carbonaceous shale with nodules of pyrite and grey silty shale, and facies $\mathrm{A}_{2}$ comprises ooidal ironstone bed (figure $3 \mathrm{a}$ and $\mathrm{b}$ ). The entire association is laterally traceable up to the right bank of the Khoh River from the Dugadda-Kotdwara and Dugadda-Ramri road junctions and reappears in the Marora road section, where it rests over the Nilkanth Formation with $1.8 \mathrm{~m}$ thick palaeosol horizon. The palaeosol horizon is distinguished by the occurrence of rootlets and pisolitic horizons. Although not very distinct, the fairly convincing pisolitic texture is very much preserved in the palaeosol horizon. In the Marora, facies $\mathrm{A}_{1}$ reduces to 2.5 $\mathrm{m}$, whereas $\mathrm{A}_{2}$ is $3 \mathrm{~m}$ thick. The thickness of this association reduces further in the Tal-Bidasini section and Nilkanth area.

\subsubsection{Interpretation}

Black shale, plane laminated fine-grained nature of sandstone and absence of any distinct wave or current features, suggests a low-energy, poorly oxygenated restricted lagoonal condition prevailed during the deposition of facies $A_{1}$. The ooidal ironstone $\left(\mathrm{A}_{2}\right)$ denotes the deposition of sediments in agitated high-energy condition. The two facies, $A_{1}$ and $A_{2}$, in association with their subfacies types are repetitive and attributed to the reducing and oxidising environments, respectively. Intermittent high-energy pulses (ooidal ironstone) might possibly explain the concurrence of these contradictory depositional units in the deeper and peripheral part of the lagoon.

Thus, after a prolonged period of non-deposition, revealed by the presence of palaeosol horizon, the Subathu sedimentation was initiated under lagoon to near shore conditions.

\subsection{Facies association- $B$}

The facies association-A is overlain by facies association-B. This association consists of grey colored shale with lensoidal sandstone and foraminiferal limestone. Shell limestone occurs at the top of this association.

It is sub-divided into three facies types, namely, facies $\mathrm{B}_{1}$ : grey shale with nodules of pyrite (with lensoidal sandstone/siltstone and poorly preserved fossils); facies $\mathrm{B}_{2}$ : grey shale, siltstone and minor bands of red and green shale along with wackestone containing foraminifera (figure $3 \mathrm{c}$ and $\mathrm{d}$; and facies $\mathrm{B}_{3}$ : grey shale with minor bands of green and red shale and packstone containing foraminifera (Assilina-Nummulite packstone).

This facies association is regionally extensive across the study area. Primary depositional feature includes thin to very thin parallel, horizontal laminae. Thin and repetitive, fining-upward laminae sets were observed in certain sections. This association tends to coarsen upward, with upper contacts being gradational with overlying heterolithic siltstone and carbonate. The gradational contact is also observed with underlying black/carbonaceous shale. These facies types also grade one into other vertically and laterally.

The thickness of this association varies from $50 \mathrm{~m}$ (Tal-Bidasini section; figure 2) to $34 \mathrm{~m}$ (Dugadda section; figure 2). Facies $\mathrm{B}_{1}$ is restricted in the Bhaun-Nilkanth, Tal-Bidasini, Marora and Dugadda sections (figure 2). Its thickness varies from 13 to $50 \mathrm{~m}$. Laterally, it pinches out and merges with the overlying facies $B_{2}$. The finegrained sandstone of facies $B_{1}$ shows varying thickness from $50 \mathrm{~cm}$ to $1 \mathrm{~m}$. Facies $\mathrm{B}_{2}$ is overlain either by facies $\mathrm{B}_{3}$ or facies association-C. Facies $\mathrm{B}_{2}$ has been recorded from all the measured 


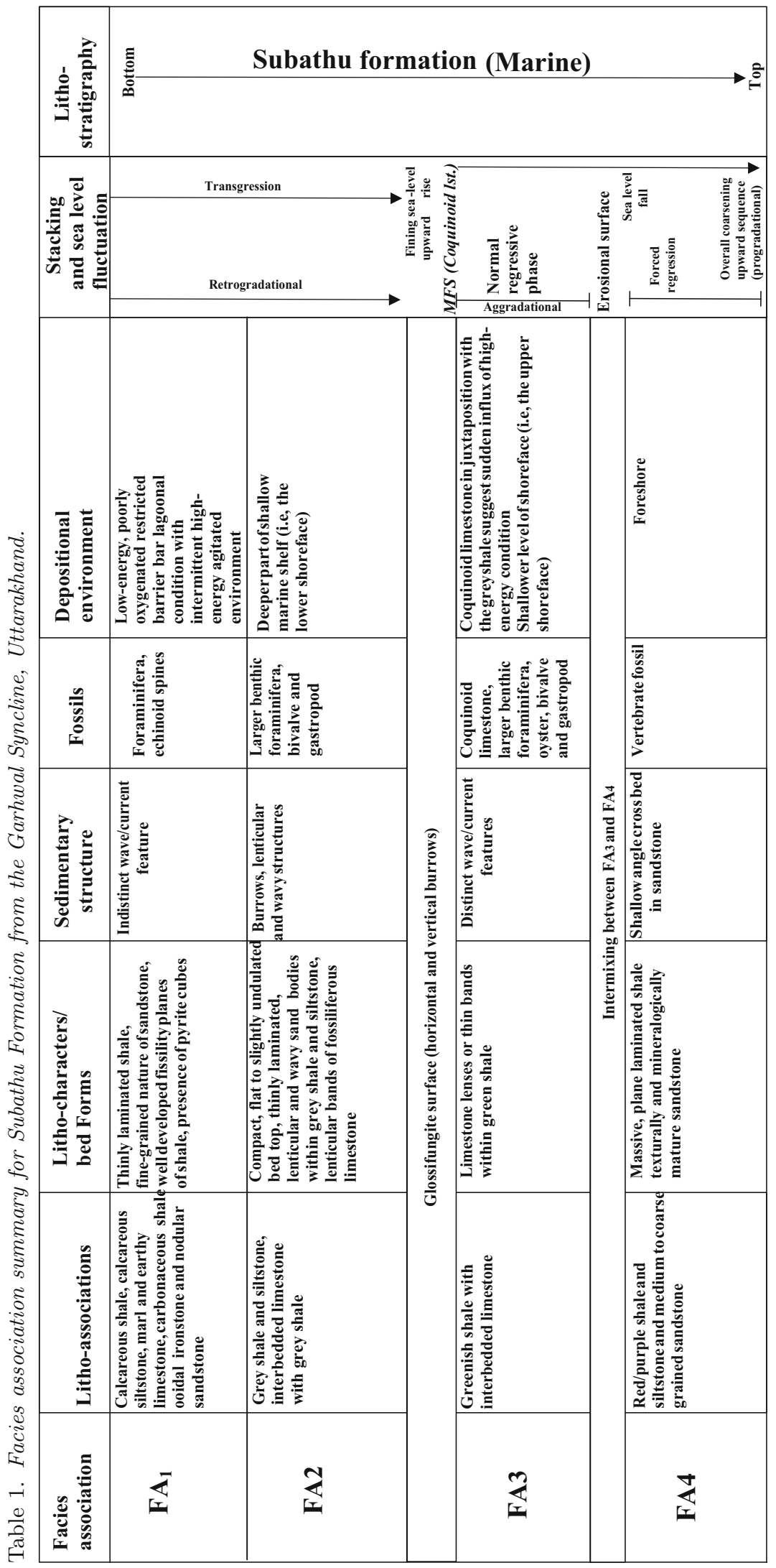



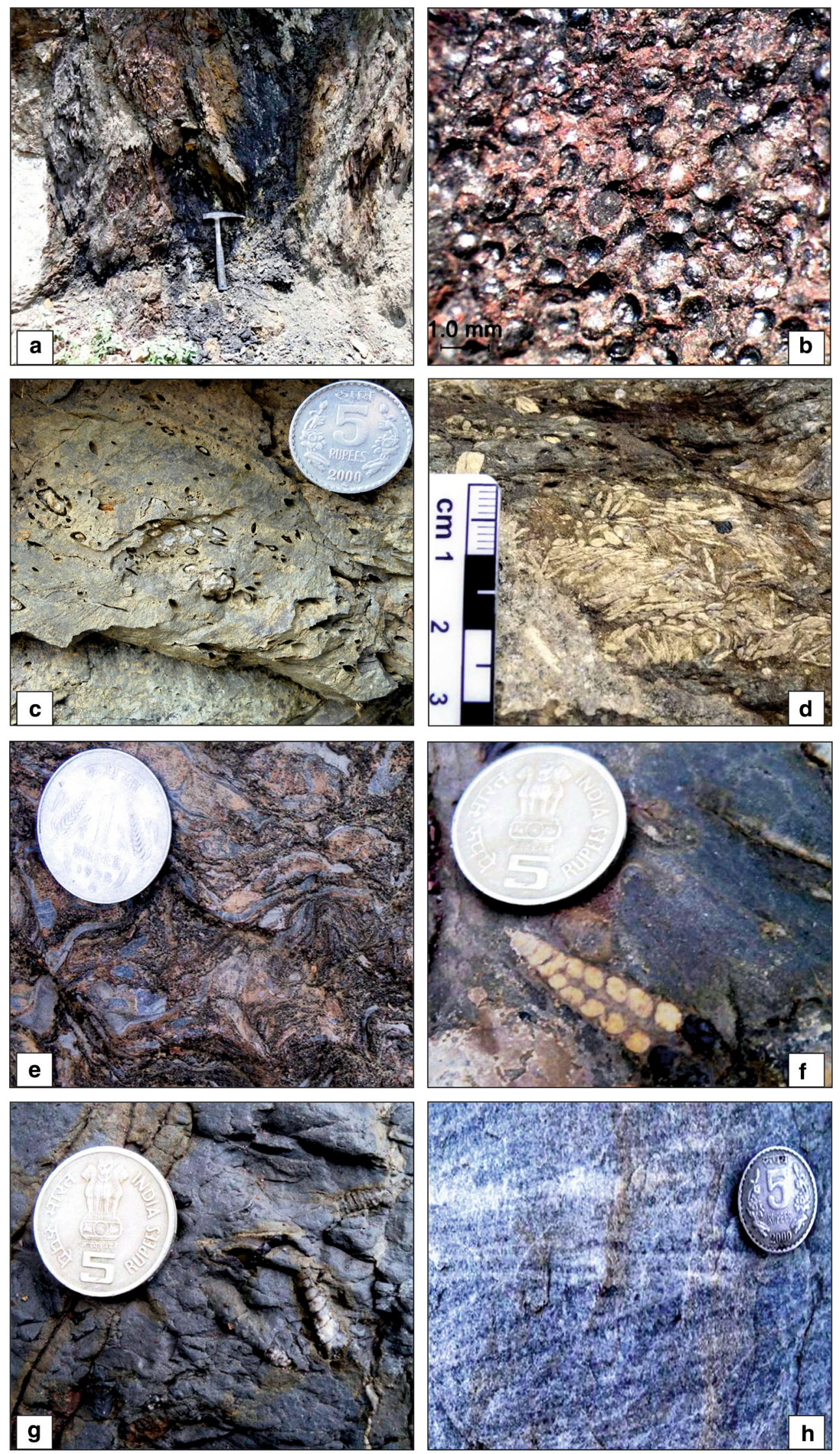

Figure 3. (a and b) Ooidal ironstone (OI) near Dugadda, Uttarakhand, (c) Nummulite in wackestone at Begra, Uttarakhand, (d) Asillina in wackestone near Nilkanth, (e) oyster bed, Tal-Bidasini section, (f and $\mathbf{g}$ ) Turritela-bearing limestone in the Tal-Bidasini section and (h) planar cross-bedded sandstone near Dugadda, Uttarakhand. 
sections. The wackestone (facies $\mathrm{B}_{2}$ ) thickness varies from $10 \mathrm{~cm}$ to $1 \mathrm{~m}$. The presence of Bryozoa has also been noticed within this facies in the Bhaun-Nilkanth section. The intercalated sequence of facies $B_{2}$ and $B_{3}$ has been observed in Dugadda. Facies $B_{3}$ conformably overlies the facies $B_{2}$. The thickness of this facies varies from 1 to $30 \mathrm{~m}$ with packstone thickness varying from $20 \mathrm{~cm}$ to $1 \mathrm{~m}$. This facies is overlain by shell limestone or coquina bed of facies association- $\mathrm{C}$ in all the measured sections.

\subsubsection{Interpretation}

Compact bed geometry, flat to slightly undulated bed top, thin laminations and a retrogradational stacking pattern, i.e., a fining-upward sequence suggests the deposition of sediments in a shallow open marine condition. The bed geometry, structures and the stacking pattern suggest a lower shoreface setting of deposition. The nummulitic shale and siltstone, in turn, are succeeded by the Assilina-Nummulite packstone. The Assilina-Nummulite packstone and the overlying the shell limestone/coquina limestone bed of facies association- $\mathrm{C}$ are present in all the measured sections and probably indicate the change in shoreline migration from transgression to regression with maximum flooding surface (MFS) defined by the Assilina-Nummulite packstone bed.

\subsection{Facies association- $C$}

The facies association-B further grades into facies association-C, comprising facies types $\mathrm{C}_{1}$ and $\mathrm{C}_{2}$. Facies $\mathrm{C}_{1}$ is represented by shell limestone or coquina bed. Indistinct hummock beds are suspected at places, though could not be ascertained with conviction due to the poor preservation of the primary structure. Facies $\mathrm{C}_{2}$ comprises green shale interbedded with fine-grained sandstone and siltstone. The shale and sandstone of $\mathrm{C}_{2}$ contain LBF (reworked), oyster (figure 3e) and gastropod (turritella). The sandstone is fine grained and the thickness varies from $50 \mathrm{~cm}$ to $2 \mathrm{~m}$. Distinct wave and current features in terms of cross beds and small ripples are also present.

This facies association is laterally persistent throughout the area and thickness ranges from 10 to $14 \mathrm{~m}$. At places like Tal-Bidasini and Bhaun-Nilkanth sections (figure 2), interbedded limestone is also recorded. In the Tal-Bidasini section, this association is represented by intercalated green shale and oyster-bearing shell limestone beds (figure 3e). The bed geometry is defined by centimetre to metre thick lenticular fossiliferous limestone which pinches out laterally. The shell limestone is succeeded by the turritella-bearing shale and sandstone intercalated sequence (figure $3 \mathrm{f}$ and $\mathrm{g}$ ).

\subsubsection{Interpretation}

The coquina limestone of facies $\mathrm{C}_{1}$ denotes the deposition in high-energy condition. This facies association-C being represented by the gastropodbearing green shale along with shell limestone is indicative of a relatively shallower environment of deposition. The facies association as a whole shows aggradation (shale and limestone intercalated sequence) to progradational (sandstone) stacking pattern. Sedimentary structures such as small scale ripples low angle cross beds and aggradation to progradational stacking pattern with the presence of coquina bed suggest the possible upper shoreface to foreshore setting of deposition. The interbedded limestone indicates less siliciclastic input from the land.

\subsection{Facies association-D}

Regionally, the facies association- $\mathrm{C}$ is overlain by red shale of facies association-D with an erosional contact. This facies association comprises Nummulite-bearing (reworked shells) red shale at its base, siltstone and medium- to coarse-grained sandstone at the top. This facies association has further been classified into two facies, $D_{1}$ and $D_{2}$. Facies $\mathrm{D}_{1}$ consists of an intercalated sequence of red shale, siltstone and thinly bedded fine-grained sandstone. The thickness of facies $\mathrm{D}_{1}$ varies from 4 to $30 \mathrm{~m}$. Facies $\mathrm{D}_{2}$ with increased sand to shale ratio is represented by red siltstone and sandstone. Sandstone is medium to coarse grain in nature. Relatively massive bedded coarse-grained sandstone with occasional shale partings is present at upper part of facies $\mathrm{D}_{2}$. Thick sandstone bodies having lenticular geometry also present in the Dugadda section. Cross-bedding within sandstone at the upper part of the facies is seen both in Tal-Bidasini and Dugadda sections (figure $3 \mathrm{~h}$ ). The sandstone unit in the Bhaun-Nilkanth section is characterised by wave ripples.

\subsubsection{Interpretation}

The basal erosional contact of this facies association suggests the exposure of the shelf due 
to the rapid fall in mean sea level (MSL). The alternate siltstone and fine sandstone with high degree of sorting suggest a continuous reworking of the sediment under the wave action. Overall, the coarsening and stacking pattern indicates the deposition in a progradational setting. The massive bed forms, both textural and mineralogical maturity, low-angle cross-beds, distinct wave features (wave ripples) also suggest the deposition under a foreshore environment.

\section{Petrography}

The facies architecture is further supplemented by the petrographic analysis which very well ascertains and correlates with the depositional environment discussed earlier. Based on the petrographic characterisation of lithologies from bottom to top (figure 4), the following nomenclature is suggested for rocks of Subathu Formation, which very well substantiates the field observations.

\subsection{Ooidal ironstone}

Petrographically, the non-skeletal and coated carbonate, i.e., ooid grains are the major constituent of the ooidal ironstone (figure 5a). The coated grains comprise a more or less well-defined nucleus, enveloped by both ferruginous and calcareous material (concentric rims). The ooids are composed of rims of either aragonite or calcite and oriented with a preferable size range of less than $2 \mathrm{~mm}$. The matrix is ferruginous in nature. The ooids comprise $25-30 \%$ of the ironstone and are well preserved. These ooids are dark grey to steel grey in colour and most of them are of uniform size. Ooids are mainly rounded in shape but few of them show deformed nature through flattening effect. The presence of composite ooid grains indicates reworking.

The presence of ooids in the rocks indicates that the deposition was taken place in a shallow marine agitated condition. Some of the ooids have quartz nuclei and some consists of calcite nuclei. The ooids cortices show the typical brownish translucent appearance. The colour may result from the included organic matter which probably plays an important part in their formation. Darker areas within the ooid cortices are probably the areas of random and equant aragonite, and perhaps are produced through micritisation of endolithic micro-organisms. Sphericity and sorting suggest deposition in high-energy condition.
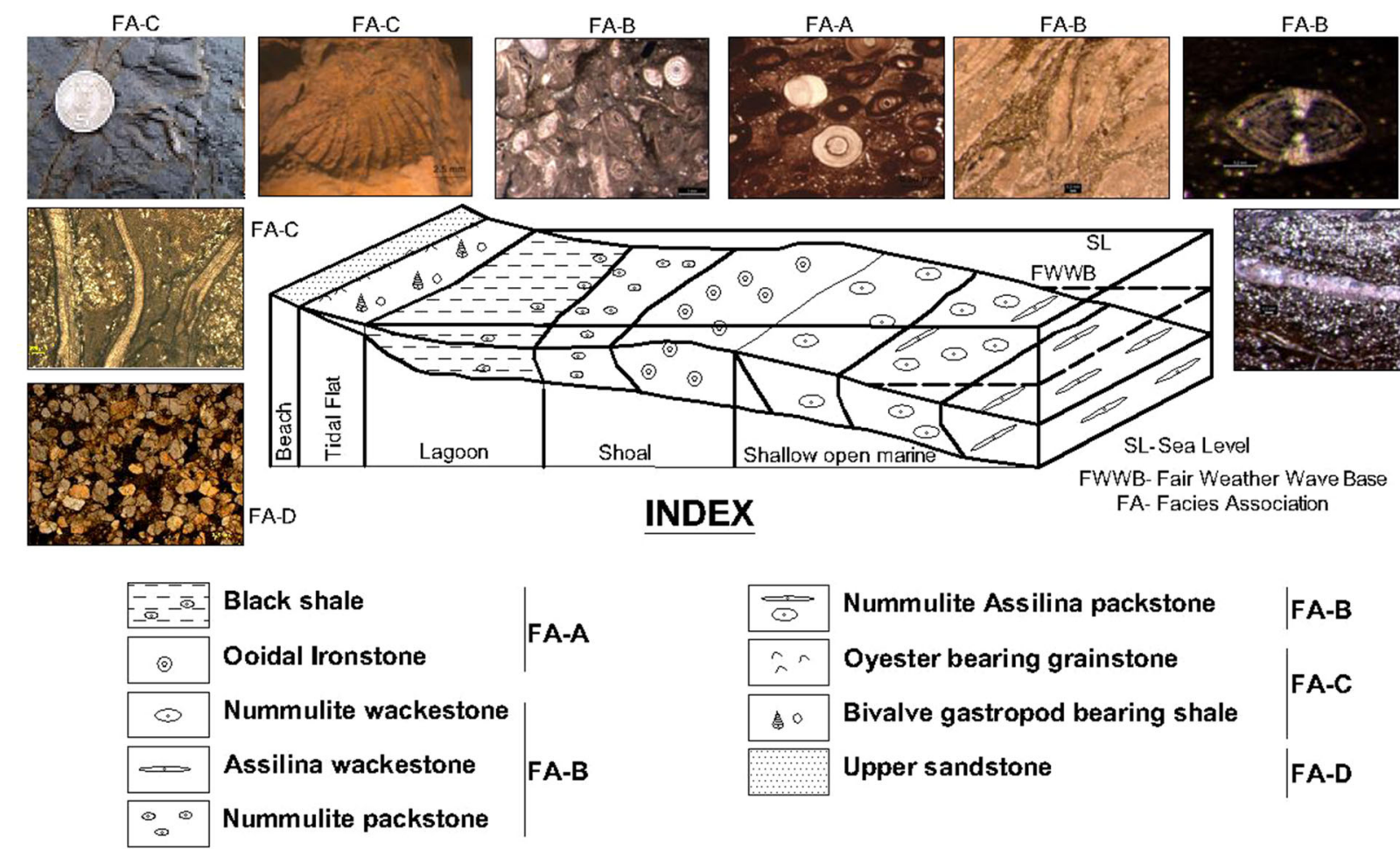

INDEX

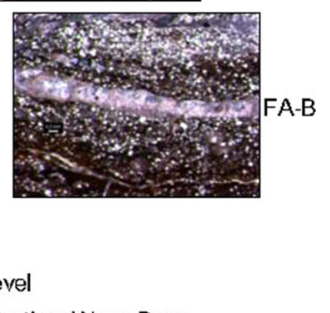

FWWB- Fair Weather Wave Base FA- Facies Association

Figure 4. A spatiotemporal facies model illustrating the depositional environment of the facies associations of Subathu Formation in correlation with the shoreline migration. 

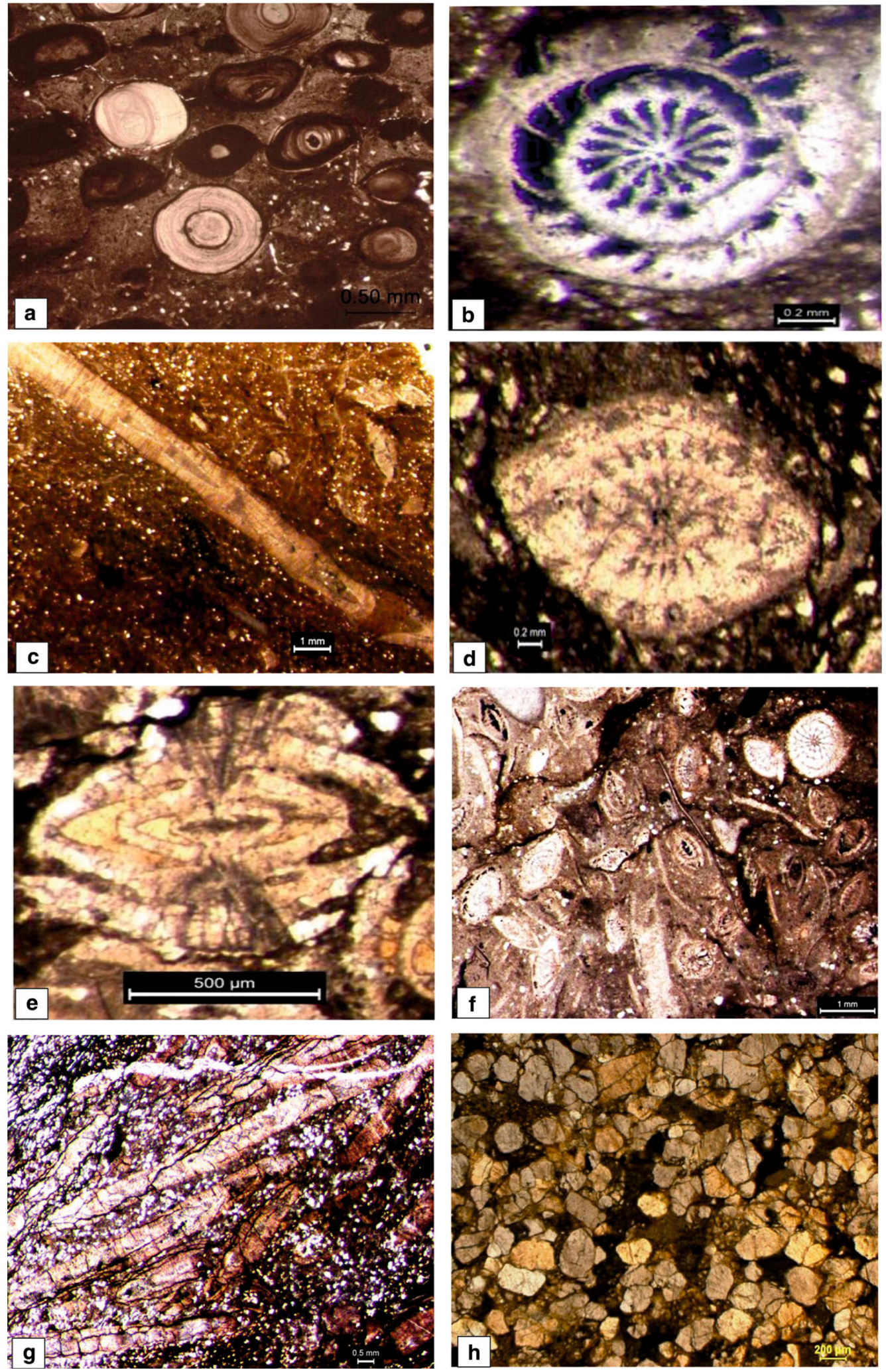

Figure 5. Photomicrographs showing (a) oolitic ironstone, the ooids of which are composed of rims of iron-rich clay mineral surrounded by aragonite or calcite, (b) the equatorial section of Daviesina sp. from the grey shale of Subathu Formation, the Duggada section, Uttarakhand. Assilina wackestone, having the bioclast of (c) Assilina spira abradi, from the limestone bed within grey shale, (d) Nummulites burdigalensis, from the grey shale, the Nilkanth section, Uttarakhand, (e) N. obtusus (Form B) from the grey shale, Duggada and Nilkanth sections, Uttarakhand, (f) Nummulite sp. forming the Nummulitic packstone, (g) Assilina-Nummulitic packstone, comprising bioclasts of both Nummulite and Assilina and (h) cross-polar view of sandstone of Subathu Formation (facies association-D). 


\subsection{Nummulitic wackestone}

Under the microscope, it is mainly characterised by quartz grains (15-25\%) and bioclast (30-40\%) mostly represented by large benthic foraminifera such as Nummulites, Assilina and Daviesina sp. (figure 5b) held in carbonate mud. Intense micritisation has taken place during diagenesis where the margins of carbonate grains are replaced by micrite at or just below the sediment-water interface. The process involves the microbes attacking the outside of the grain by boring small holes in them, which are later filled with micritic mud. Matrix occupying the space between the allochem grains is fine-grained aphanitic mud with least admixture of any terrigenous material. Based on the matrix percentage, composition and relative elongate shape of the Nummulite shells, the lithological association is believed to be of deeper part of a shallow marine environment and corresponds to facies association-B.

\subsection{Assilina wackestone}

Under the microscope, this lithology largely consists of micrite (70-80\%). Quartz grains are also present substantially. The allochems together contribute about $20 \%$ of the framework grains. The presence of in-situ as well as broken bioclasts of Asillina (figure 5c), Nummulites (figure 5d and e), echinoderm and corals indicates towards highenergy marine and lacustrine environments where currents and waves result in the vigorous winnowing and abrasion of the shells. The presence of Nummulites is very minimal. It indicates a relatively deep water $(50-80 \mathrm{~m})$ in open marine setting (Racey 1994). This is correlatable with the middle to upper part of facies association-B.

\subsection{Nummulitic packstone}

Nummulitic packstone is represented by the dominance of Nummulite (figure 5f) although numerous broken fragments of bivalves are also found in this particular lithology. It comprises grains of quartz and bioclast bounded by the carbonate cement. Bioclasts (20\%) are mainly of bivalve and Nummilite shell fragments. Two generations of cementation are observed. Thin micrite cementation of earlier generation present on the original grain surface. Later due to the effect of diagenesis the earlier micrite, in turn, transforms into sparitic cement. The Nummulite shells are relatively globular and flattened, rather elongated. The relatively lesser matrix percentage and grain supported nature categorise this lithology, which is to be deposited in the upper part of the shallow marine shelf environment. With these characteristics, it is believed to occur at the middle to upper part of the facies association-B.

\subsection{Nummulite-Assilina packstone}

It comprises both Assilina sp. and Nummulite sp. Under the microscope, this lithounit is highly fossiliferous consisting of $60-70 \%$ bioclasts of Nummulites-Assilina sp. (figure $5 \mathrm{~g}$ ), bivalve, gastropod and other fossil groups. These bioclasts are randomly distributed. Both broken and intact shell fragments of these bioclasts are present. Quartz grains occur in lesser quality. The micritic mud forms the main orthochemical component in which the bioclasts are found to be embedded. The ovate-shaped Nummulites occur as in-situ, whereas Assilina is derived from the deeper level and deposited in shallow water depth, possibly by means of storm condition. All these evidences along with the petrographical characteristics place it in the transition zone between the facies association$\mathrm{B}$ and $-\mathrm{C}$.

\subsection{Oyster-bearing grainstone}

It is represented by the grain supported framework structure. The intergranular space is filled with calcite cement. Petrographically, it consists of both broken and intact bioclasts, more than $50 \%$ in abundance and are found to be randomly distributed (mostly they are of bivalve shells and oysters). Grains of quartz and iron oxide are dominantly present in this rock (10-15\%). The skeletal grains are found to be present within the micritic matrix which is nothing but the carbonate mud. The carbonate detritus consists of fragments of preexisting limestone, i.e., the intraclast and the fossil fragments. The percentage of the matrix is very less due to continuous reworking. Spary calcite is the cementing material. Under higher magnification, the crystalline growth of the sparite during the diagenesis is very much prominent. However, the crystal growth is restricted within the pore spaces, i.e., the drusy crystallisation structure. The above-described characteristic features indicate a relatively higher energy condition as compared to the previous lithologies. This lithological unit along with the preceding one defines the end of the facies 
association-B as well as marks the lower part of facies association- $\mathrm{C}$ and denotes the deposition in high-energy condition.

\subsection{Bivalve gastropod-bearing shale and limestone}

Petrographically, it consists of both broken and intact bioclasts (50\%). They are randomly distributed (mostly bivalve shells). The matrix is micritic in nature. However, at places, these micrites are transformed into sparitic cement. The presence of turritella and other bivalves brings its affinity more towards the near shore deposits and its equivalence to facies association-C.

\subsection{Upper sandstone}

Petrographically, it can be described as the subrounded-subangular grains of quartz (80\%), lithic chert fragments and opaque mineral (figure 5h). The intergranular spaces between the mineral constituents are filled by both the siliceous and micaceous matrices. The cementing material is ferruginous in nature. Sub-rounded nature of quartz suggests fair transportation before the deposition. The high abundance of quartz grains represents compositionally/mineralogically mature rock, so as the high degree of sorting attributes to the textural maturity of the rock (figure $5 \mathrm{~h}$ ). The line as well as sutured contact between the grains at places might be the result of high compaction. These petrographic characteristics are suggestive of foreshore or beach environment of deposition which is correlatable with the facies association-D.

\section{Discussion}

The facies type varies in palaeoenvironment of deposition from restricted lagoonal to foreshore through a transgressed shoreface setting (both lower and upper shorefaces). In all the lithosections of the Garhwal Syncline (stretching over $80 \mathrm{~km}$ ), the invariable presence of key stratigraphic horizons/levels such as the oodial ironstone, coquina limestone and erosional surface at the base of upper sandstone strongly establishes a relationship between the Subathu sedimentation and the relative sea level changes within the basin.

The facies analysis correlates with genetically related lithologies as facies association, describing how the sedimentation has taken place within the basin in accordance with shoreline migration.
The facies association-A with the predominant oolitic ironstone horizon along with the carbonaceous shale, basal nodular sandstone, grey silty shale, marly and calcareous siltstone accounts to intermittent pulses of high-energy condition within a calm and less disturbed environment of deposition. This facies association also marks the onset of marine transgression for the Subathu sedimentary sequence. The gradational trend shifts in lithology form facies association-B to facies association-C with the coquina limestone at the juxtaposition suggests that the progradation was gradual and of basin scale.

Both extrabasinal and intrabasinal events possibly contributed to the deepening-upward trend during the period of transgression, as the mean sea level started approaching towards the continent, the deeper water sediments started to on lap over the shallow marine sediments along with detritus supply from the continent. This has given rise to a fining-upward sequence for the facies association-A and $-\mathrm{B}$ in terms of retrogradational stacking pattern. Further, the facies association-C and -D reveal the shallow to transitional marine associations with an overall progradational stacking pattern. In the stratigraphic record, such coarsening-upward marine to coastal strata are interpreted as a sign of progressive inward deepening (Bourgeois 1980; Emery and Myers 1996). This irreversible transition from the submarine to the subaerial condition with pronounced basal and upper basin-scale discontinuity supports a regional fall in the sea level.

A spatio-temporal facies model for the depositional environment of the above facies associations in correlation with the shoreline migration has been proposed (figure 4). This model further explains the sedimentation and stacking pattern of different lithopackages of the Subathu Formation. The onset of transgression with proximal lagoonal carbonaceous shale/ooidal ironstone deposit is further supplemented by the onlapping of the deeper water lithofacies over the shallower by means of a finingupward stacking pattern. Hence, it depicts deposition in transgression, wherein the grey and green shale units have come over the lagoonal facies with basin deepening. However with the normal regression, where the rate of sedimentation has outpaced the relative increase in the mean sea level and hence the interbedded character between the grey and green shale units suggests that the progradation was gradual and of basin scale with corroborative evidence in terms of increasing sandstone, the shale 
ratio documented and correlated over the measured sections. Sedimentological studies suggest that the upper Subathu Formation represents laterally persistent foreshore deposit on the starved shelf.

\section{References}

Allen P A, Crampton S L and Sinclair H D 1991 The inception and early evolution of the North Alpine foreland basin, Switzerland; Basin Res. 4 143-163.

Auden J B 1937 The structure of the Himalaya in Garhwal; Rec. Geol. Surv. India 71 407-433.

Bera M K and Mandal A 2013 Forced regressive across the marine to continental transition in Jammu subbasin: Implication to the Oligo-Miocene unconformity in Himalayan foreland; J. Asian Earth Sci. 67-68 37-45.

Bera M. K, Sarkar A, Chakraborty P P, Loyal R S and Sanyal P 2008 Marine to continental transition in Himalayan Foreland. Geol. Soc. Am. Bull. 120(9-10) 1214-1232.

Bera M K, Sarkar A, Chakrabarty P P, Ravikant V and Choudhury A K 2010 Forced regressive shoreface sandstone from Himalayan foreland: Implications to early Himalayan tectonic evolution; Sedim. Geol. 229 268-281.

Bourgeois J 1980 A transgressive shelf sequence exhibiting hummocky stratification: The Cape Sebastian Sandstone (Upper Creatceous), Southwestern Oregon; J. Sedim. Petrol. 50 681-702.

Bhatia S B 1982 Facies, fauna and flora of the Lower Tertiary formations of Northwestern Himalaya; J. Palaeontol. Soc. India 1 8-20.

Bhatia S B 1985 Some aspects of the Early Tertiary biostratigraphy and palaeogeography of the Indian subcontinent; Q. J. Geol. Min. Metal. Soc. India 57 63-98.

Chaproniere G C H 1975 Palaeoecology of Oligo-Miocene larger foraminiferida, Australia; Alcheringa $137-58$.

DeCelles P G and Giles K A 1996 Foreland basin systems; Basin Res. 8 105-123.

Emery D and Myers K J 1996 Sequence stratigraphy; Blackwell Science, Oxford, 297p.

Hottinger L 1983 Processes determining the distribution of larger foraminifera in space and time; Utrecht Micropaleontol. Bull. 30 239-253.

Hottinger L 1997 Shallow benthic foraminiferal assemblages as signals for depth of their deposition and their limitations; Bull. Soc. Geol. Fr. 168 491-505.
Mathur N S 1978 Biostratigraphical aspects of the Subathu Formation, Kumaun Himalaya; Recent Res. Geol. 5 96-112.

Mathur N S and Juyal K P 2000 Atlas of early palaeogene invertebrate fossils of the Himalayan foothills belt (Monograph Series); Wadia Institute of Himalayan Geology, Bishen Singh Mahendra Pal Singh, Dehradun.

Medlicott H B 1864 On the geological structure and relations of the southern portion of the Himalayan Range between the Rivers Ganges and Ravee; Mem. Geol. Surv. India 3(2) 1-212.

Najman Y, Clift P, Johnson M R W and Robertson A H F 1993 Early stages of foreland basin evolution in the Lesser Himalaya, N. India; In: Himalayan tectonics (eds) Treloar P J and Searle M P, Geol. Soc. London, Spec. Publ. 74 541-558.

Racey A 1994 Biostratigraphy and palaeobiogeographic significance of Tertiary nummulitids (Foraminifera) from northern Oman; In: Micropalaeontology and hydrocarbon exploration in the Middle East (ed.) Simmons M D, Chapman and Hall, London, pp. 343-370.

Sarkar S and Prasad V 2000 Palynostratigraphy and depositional environment of the Subathu Formation, Morni hills, Haryana, India; J. Paleontol. Soc. India $45137-$ 149.

Sinclair H D 1997 Tectonostratigraphic model for underfilled peripheral foreland basins: An Alpine perspective; Geol. Soc. Am. Bull. 109 324-346.

Singh B P 2012 How deep was the early Himalayan foredeep? J. Asian Earth Sci. 56 24-32.

Singh B P 2013 Evolution of the Paleocene succession of the western Himalayan foreland basin; Geosci. Front. 4199 212.

Singh B P, Pawar J S, Singh Y R, Singh G P and Srivastava A 2010 Marine to continental transition and sequence stratigraphy in a Paleogene succession of the Western Himalayan Foreland Basin, India; Gond. Geol. Mag. 25(2) 195-211.

Valdiya K S 1980 Geology of Kumaon Lesser Himalaya; WIHG, Dehra Dun.

Ziegler P A, Cloetingh S and van Wees G D 1995 Dynamics of intra-plate compressional deformation: The Alpine Foreland and other examples; Tectonophys. 252 7-59.

Ziegler P A, Van wees J D and Cloetingh S 1998 Mechanical controls on collision related compressional intraplate deformation; Tectonophys. 300 103-129. 